\title{
Estimating the economic payoff to virtual university education: a case study of the Open University of Catalonia
}

\author{
Jonatan Castaño-Muñoz ${ }^{1,2} \cdot$ Martin Carnoy ${ }^{3,4}$ • \\ Josep M. Duart ${ }^{2}$
}

Published online: 22 September 2015

(C) The Author(s) 2015. This article is published with open access at Springerlink.com

\begin{abstract}
There is surprisingly little analysis of the employment and earnings impact on students of taking and completing Internet-based programs and of how it compares with earnings outcomes for graduates of face-to-face universities. This paper analyzes a followup survey of students who began attending the virtual Internet-based Open University of Catalonia (UOC) in the early 2000s. We find that, on average, they made smaller percentage gains in earnings than workers of similar age and initial education in the Spanish labor market. Yet, we also find that many of our UOC respondents were "high flyers," already earning high salaries when they had begun studying at UOC. When we separate them out, we find that younger, more "normal" UOC students made larger earnings gains than the comparison group in the Spanish labor market. We emphasize the importance of disaggregating the varied clientele of online universities in assessing their economic payoffs.
\end{abstract}

Keywords Online universities · Economic payoffs · Adult learners · E-learning

Jonatan Castaño-Muñoz

jonatan.castano-munoz@ec.europa.eu

Martin Carnoy

carnoy@stanford.edu

Josep M. Duart

jduart@uoc.edu

1 Institute for Prospective Technological Studies, Joint Research Centre, European Commission, Seville, Spain

2 Universitat Oberta de Catalunya (UOC), Barcelona, Spain

3 School of Education, Stanford University, Stanford, CA, USA

4 International Laboratory for Educational Policy Analysis, National Research University Higher School of Economics, Moscow, Russian Federation 


\section{Introduction}

Increasing numbers of working adults and college-age students are relying on distance, Internet-based education to acquire specialized knowledge and college degrees. In many countries, virtual universities offering such courses and degrees are among the largest enrollment higher education institutions. Despite "virtual" education's growing importance and its potential effect on lifelong learning and changing patterns of work and study, there has been surprisingly little analysis of the employment and earnings impact on students of taking and completing Internet-based programs and of how this impact compares with earnings outcomes for graduates of traditional face-to-face universities. The analysis is made more complex because most students at distance learning universities choose this more flexible form of higher education because they work full time and are considerably older than those attending traditional universities (Ozdemir et al. 2008).

Studies on the economic payoff to adults investing in higher education have been mainly focused on Britain (Bennion et al. 2011). Their results suggest that females benefit more than males from lifelong learning (De-Coulon and Vignoles, 2008; Blanden et al. 2012), that least educated individuals are less likely to participate, but when they do, are more likely to benefit (Blundell et al. 1997; Myers and Myles, 2005), and, most important in terms of our research, that adults have smaller returns to investing in higher education than traditional-age younger students (Steel and Sausman, 1997; Egerton and Parry, 2001; Blundell et al. 1997; Jenkins et al. 2002).

The few studies outside of Great Britain support this finding on returns for younger and older workers to investing in higher education (e.g., OECD, 2003, Box 4.2) But a more recent study in Britain (Dorset, Liu, and Weale, 2010) disagrees, arguing that earlier work does not account for the higher probability that adults will find employment when they take more education and that, therefore, payoffs to adults are more comparable with payoff to the investment in higher education by traditional students. A recent Swedish study (Hällsten 2012) confirms this argument. It shows how late degrees have large employment effects, but small effects on earnings once the adult is employed. Additionally, this study shows that the effects disappear at the higher end of the earnings distribution.

As far as the payoff to distance education learners, the research is sparse. Woodley and Simpson (2001) surveyed a sample of about 4500 Open University (UK) adult students who had graduated from 1990 to 1995 (before the onset of online distance education), and estimated that these graduates had a relatively high monetary return to their investment despite beginning their studies as adults. According to the study, OU graduates had a $10 \%$ increase in earnings between graduation and the time of the survey relative to the national average for women, and $6 \%$ for men. Woodley and Simpson's conclusions are beset by issues of selection bias inherent in studies of adult learners and particularly adult learners studying distance courses for degrees, but the authors made a unique attempt to estimate the earnings gains of distance learning graduates.

It is important to distinguish the "distance education" that preceded the advent of the Internet from today's Internet-based online education. Although both are based on similar systems of structured curricula and student-live tutor interaction for correcting work and getting feedback, online distance education can monitor student use and progress, provide alternative and effective interactive and collaborative tools (Castaño-Muñoz et al. 2014), and evaluate tutors and students in multiple ways not available to traditional distance learning. Further, students using the Internet for online education may be learning information and communication technology (ICT) skills above and beyond the skills imparted 
by the actual courses they are taking. Such ICT skills could enhance the future earnings of online university students (Lanvin and Passman, 2008; Ben Youssef et al. 2013). However, it must be noted that students in traditional face-to-face universities are also heavy ICT users, mainly in social media, but for homework and for communicating with professors as well (Castaño-Muñoz and Senges, 2011). As ICT use among students becomes ubiquitous, the ICT advantage of online students declines.

In this paper, our main goal is to estimate the economic (earnings) payoff to those who take online education and are employed compared with those in the labor force as a whole of similar education and age. We build on the OU study and our own earlier work (Carnoy et al. 2012a, b) to analyze a new round of unique follow-up surveys of students who have attended a large completely virtual, Internet-based, distance learning university in Barcelona, Spain - the Open University of Catalonia (UOC). The UOC currently has more than 50,000 students, mostly in Catalonia, but also in the rest of Spain. In the earlier studies, we estimated both the survival rates of students studying various courses in the UOC and the reported participant earnings before studying at the UOC and their earnings one year after leaving their UOC studies. We compared UOC students' earning gains over the period with similarly educated workers of similar age in the overall Spanish labor market. As far as we can determine, our studies are the only ones that compare the economic payoffs to online university students (even indirectly) with those educated in traditional face-to-face higher education.

In the research we report here, we surveyed the same individuals in 2012 about their pre-UOC earnings and their current earnings. Even with important changes in the condition of the Spanish economy in 2009-2012, this second round of interviews allowed us to get more accurate information than in 2009 on respondents' earnings and whether they completed their UOC degree. Further, respondents in our more recent survey averaged 11 years older than when they first enrolled in UOC courses (40-46 years old). At this age, they have, in effect, reached "maturity" in the labor market regarding changes in the slope of their age-earnings profiles resulting from their UOC education. Comparisons with similar workers in the larger Spanish labor market should therefore be fairly definitive in assessing the gains from a UOC education and more traditional university education.

The paper is divided as follows: The second section discusses our data, "Estimation strategy" section presents our empirical strategy, "Results" section presents the results, and "Discussion and conclusions" section concludes with a discussion of our findings.

\section{Data}

We use a 2012 follow-up telephone survey of a sample that we originally surveyed in 2009. The original survey consisted of more than 1700 UOC students who had enrolled at UOC's Catalan and Spanish "virtual campuses" in the six semesters of 2000-2002 and at the Spanish "virtual campus" in the first semester of 2003 (to get a sufficiently large sample from that "campus"). Most of those in the original survey had not completed the degrees for which they enrolled, even though they were surveyed at least 6 years (and, typically, 8 years) after having matriculated. In addition, a vast majority of those surveyed were or had been enrolled in programs that required only two or 3 years of courses to complete.

In the 2012 follow-up survey, we were much more careful in capturing current income and identifying whether UOC students had graduated with a degree. Thus, although the total number of former students who answered the telephone survey in the 2012 follow-up 
was considerably smaller than in 2009 (718 vs. 1700), the number for whom we were able to capture "before-UOC" and "after-UOC" earnings was higher than in 2009 (528 vs. 438). We are also more confident that in the second survey "after-UOC" earnings are more accurate than in the first survey.

The second data set we use in the study is from a survey taken every few years by the Spanish National Institute of Statistics (INE) of employed workers and their earnings, education, occupation, age, and other related variables (INE 2015). The INE data we used were from the employment survey of 2002, which corresponds to the year after the median year in which our UOC sample was entering their UOC studies (2001), and the employment surveys of 2006 and that of 2010, the latest employment survey currently available. We use the Spanish consumer price index as reported by INE to project these INE survey incomes in 2002 back to 2001 and the 2010 incomes forward to 2012. On the basis of these comparisons, we are able to estimate the possible gains for UOC attendees relative to projected average gains for Spanish workers as a whole in the 11 years, 2001-2012.

Because we could only get data on employed Spanish workers from the INE surveys, the earnings data we used from our UOC surveys are restricted to those who reported earnings (were employed) in both 2001 and 2012.

However, it is important to note that labor market conditions in Spain in the early 2000s-when those in our sample reported "before-UOC" earnings and those surveyed by INE in 2002 reported their earnings-were considerable better than in 2009 and particularly in 2012, when those in our earlier and current UOC surveys reported their earnings and in 2010 when INE surveyed employed Spanish workers. The 2008 US/European banking crisis and the collapse of the Spanish real estate bubble hit Spain's economy particularly hard. Although the overall unemployment rate was already high in the earlier period-14 and $11 \%$ in 2000 and 2001-it was even higher in 2009-2010 (18-20\%) and much higher in $2012(25 \%)$.

The average earnings reported in 2010-2012 should have been negatively affected relative to the average earnings reported for 2001 because of downward pressure on earnings exerted by higher unemployment rates. The biases may not be as large for middleaged university educated labor-our group of interest-because its unemployment rate is considerably lower. For example, in our UOC survey, only $8 \%$ of respondents in 2012 said they were unemployed. Furthermore, if the biases are similar in the two data sets, the comparisons of gains between the two are probably not biased. We discuss the various sources of bias in our estimates further in the estimation strategy and results sections.

\section{Estimation strategy}

We take two approaches to estimating earnings gains for online university students who initially enrolled at the UOC in 2000-2003. In the first approach, we use our survey data to estimate the reported mean earnings in 2001 - the mean year for which our sample cohorts estimated their "before-UOC" earnings-and the reported average earnings in 2009 and 2012, the years we conducted our UOC follow-up surveys, for the 483 individuals in our 2012 survey that also reported "before-UOC" earnings in the 2009 survey. We decided that the "before-UOC" earnings reported in the earlier survey were more accurate than those reported in 2012 because they were reported closer in time to the actual event. Nevertheless, the differences between the before-UOC earnings reported in the 2009 and 2012 surveys by the same individuals are generally small. The other issue is how the 
earnings of the smaller group (483) of individuals who reported before-UOC earnings in both 2009 and 2012 compare to the larger group (648) for which we have before-UOC earnings just in 2009. There are two cases in which the average earnings of the more restricted group (the one we use in this study) are considerably higher than for the larger sample (2009 only): those who studied law, psychology, or humanities and those who studied business sciences. Thus, earnings gains may therefore be underestimated for these two groups. ${ }^{1}$

We also compare the average earnings gains in 2001-2012 for our sample of UOC students with the average earnings gains for all Spanish workers of similar initial education and age, using the INE employment survey data described above. The INE data also provide information on the gender and occupation of employed workers in the Spanish labor force, so we are able to estimate and compare the relative earnings gains among male and female UOC students by program of study to gains of their counterparts in the Spanish labor force by occupations similar to UOC programs of study. In order to compare the UOC sample with Spanish workers by "occupation," we are forced to assume that UOC students who followed a certain program of study worked in an occupation that fit their study program.

In the second approach, we estimate earnings functions to understand the factors that are most important in explaining the variation in earnings gains for UOC enrollees. We use a standard "value added" approach (Ladd, 2008) to estimating the log of 2012 earnings reported by our respondents in the UOC 2012 follow-up survey as a function of "beforeUOC" earnings reported by the same respondents on the 2009 survey, their age, gender, whether they changed firms or changed jobs in the same firm, and several different definitions of their program of study. This provides estimates of the relative contribution to the earnings "gains" of the student's program of study controlling for age, gender, and job/firm change.

We estimate the following general model using ordinary least squares (OLS):

$$
\log Y_{i j 2012}=\alpha \log Y_{i j 2001}+\beta \mathrm{X}_{i j}+\gamma W_{i k}+\Sigma \delta_{j} \Pi_{i j}+\varepsilon_{i j}
$$

where $Y_{i k}=$ reported annual earnings of former UOC student $i$ in study program $j$ in 2012 (after UOC) or 2001 (before UOC); $X_{i j}=$ a vector of individual characteristics-age, age squared, and gender; $W_{i j}=$ change in job within firm or change in firm in 2001-2012 of former student $I ; \Pi_{i j}=$ former UOC student $i$ 's program of study $k ; \varepsilon_{i j}=$ an error term.

As noted above, we limited our analysis to those sampled that reported having earnings in both 2001 and 2012. This may result in selection bias, since not all those in our survey were employed both in 2001 and in 2012. Of the 710 individuals in our survey in 2012 who reported their work status both before UOC and in 2012, 674 were employed before UOC (2001), and 36 were not employed (unemployed, students, or domestic workers). Of these 674, 65 were not employed in 2012 (50 were unemployed, nine retired, three were students, and three were domestic workers), and another 22 who were not employed in 2001 were employed in 2012.

To check for the robustness of our estimates of the impact of various UOC courses of study on earnings gains $\left(\delta_{j}\right.$ 's), we undertook an alternative estimate of the $\delta_{j}$ 's) - one in

\footnotetext{
1 The before-UOC average earnings of the 2009 sample of those who attended the law, psychology, or humanities programs were 27,700 euros for men and 16,300 euros for women. Those who attended business sciences reported pre-UOC earnings in the 2009 survey of 29,600 euros for men and 18,200 euros for women. All these figures are considerably lower than the earnings we use for our estimates of gains (see results, below).
} 
which we imputed the earnings in 2012 of all those employed in 2012 who reported earnings pre-UOC (2001). We also examined possible biases from not including those in the sample who had reported earnings pre-UOC but were unemployed in 2012 . $^{2}$

Our estimates of the "effects" on earnings of various study programs are also subject to a different kind of selection bias, namely that students who enter programs associated with larger earnings gains may be more motivated or of higher ability. We reduce this type of selection bias by controlling for previous income, since higher ability individuals probably earn higher initial income. As discussed below in the results section, we also controlled for other variables as checks on selection bias, with minimal changes in our estimated coefficients for program of study on log earnings.

Finally, due to the correlation of student error terms within as opposed to between schools, we estimate cluster-corrected Huber-White estimators for Eq. (1), in which former students are considered to be clustered in study programs. ${ }^{3}$

\section{Results}

The follow-up survey was taken approximately 11 years after the "median student" in the survey had originally entered the UOC. In 2012, the mean age of respondents was 43 years old, and less than one-half indicated that they had obtained a degree in their UOC program of study (Table 1). This is a relatively low proportion but not much different from a typical face-to-face university. In the first decade of the 2000s, according to UNESCO statistics, about $40 \%$ of those enrolled in undergraduate programs in Spanish universities graduated (UNESCO 2015), but other, earlier longitudinal (1996-2003) studies estimate somewhat lower rates (Lassibille and Navarro Gomez 2009). The completion rates in these types of degrees are similar in UOC; they are higher in two-year "professional degree" courses of study. One reason for the low completion rate in UOC that differentiates it from a face-toface university in Spain is that $57 \%$ of those who responded in the survey already had degrees when they entered the UOC-32 \% reported having a diploma degree and $25 \%$, a "licenciatura." As might be expected, the largest group in the survey respondents was or had been enrolled in business administration or business sciences $(30 \%)$ and the second largest group, in one of the three information technology courses of study (23\%).

\section{Average earnings gains for UOC students and graduates}

From the questionnaire, we were able to calculate the average reported annual earnings before, during, and after studying in the UOC by program of study. Table 2 only shows the "before-UOC" and the 2012 earnings (after UOC) for the interviewees for whom we got earnings data in both 2009 and 2012 (hence, those who were employed in both 2001 and 2012), as well as for those who graduated with degrees from UOC in that period. The overall average annual earnings for men rose from 27,210 euros before they entered UOC

\footnotetext{
${ }^{2}$ For the imputation of earnings for all those who were employed in 2012 but did not report earnings, we used their individual and family characteristics, pre-UOC earnings, and their study program in the UOC to predict their 2012 earnings. Our estimates may also be subject to heteroscedasticity. We used a BreuschPagan/Cook-Weisberg test for heteroscedasticity and found that we only faced a problem in our estimates for UOC graduates when we used more detailed definitions of study programs. Once we introduced a cluster correction in all the regressions, this heteroscedasticity problem was largely eliminated.

${ }^{3}$ Cluster correction to estimate unbiased standard errors is standard practice in the economics of education literature. An alternative to hierarchical linear model estimates.
} 
Table 1 UOC 2009 and 2012 survey of UOC student cohorts 2000-2002/2003, variable means

\begin{tabular}{|c|c|c|c|c|c|}
\hline Variable & $\begin{array}{l}\text { Total } \\
\text { sampled }\end{array}$ & Mean $(\%)$ & Variable & $\begin{array}{l}\text { Total } \\
\text { sampled }\end{array}$ & $\begin{array}{l}\text { Mean } \\
(\%)\end{array}$ \\
\hline Age & 713 & 43.1 years & Degree program & 718 & \\
\hline Gender (male) & 718 & 51.5 & $\begin{array}{l}\text { Personnel and labor } \\
\text { management }\end{array}$ & 59 & 8.2 \\
\hline Married & 716 & 76.5 & Asia studies & 1 & 0.1 \\
\hline Average number of children & 716 & 1.2 & Marketing & 9 & 1.3 \\
\hline Family education primary & 699 & 49.4 & Library science & 30 & 4.2 \\
\hline Family education secondary & 699 & 27.3 & Psycho-pedagogy & 33 & 4.6 \\
\hline Family education university & 699 & 23.3 & Business administration & 55 & 7.7 \\
\hline $\begin{array}{l}\text { Previous education } \\
\text { secondary }\end{array}$ & 717 & 43.1 & Business sciences & 163 & 22.7 \\
\hline $\begin{array}{l}\text { Previous education } \\
\text { diplomatura }\end{array}$ & 717 & 31.9 & Policy studies & 7 & 1.0 \\
\hline $\begin{array}{l}\text { Previous education } \\
\text { licenciatura }\end{array}$ & 717 & 25.0 & $\begin{array}{l}\text { Audiovisual } \\
\text { communications }\end{array}$ & 7 & 1.0 \\
\hline Received UOC degree & 718 & 51.8 & Law & 49 & 6.8 \\
\hline $\begin{array}{l}\text { Work situation pre-UOC } \\
\text { employed }\end{array}$ & 718 & 96.0 & $\begin{array}{l}\text { IT information } \\
\text { management }\end{array}$ & 70 & 9.8 \\
\hline $\begin{array}{l}\text { Work situation pre-UOC } \\
\text { student }\end{array}$ & 718 & 1.7 & IT information systems & 75 & 10.4 \\
\hline $\begin{array}{l}\text { Work situation pre-UOC } \\
\text { unemployed }\end{array}$ & 718 & 1.4 & Information engineering & 17 & 2.4 \\
\hline $\begin{array}{l}\text { Work situation pre-UOC } \\
\text { other }\end{array}$ & 718 & 1.0 & $\begin{array}{l}\text { Catalan language and } \\
\text { literature }\end{array}$ & 8 & 1.1 \\
\hline $\begin{array}{l}\text { Work situation post-UOC } \\
\text { employed }\end{array}$ & 712 & 88.9 & Humanities & 37 & 5.2 \\
\hline $\begin{array}{l}\text { Work situation post-UOC } \\
\text { student }\end{array}$ & 712 & 0.6 & Psychology & 89 & 12.4 \\
\hline $\begin{array}{l}\text { Work situation post-UOC } \\
\text { unemployed }\end{array}$ & 712 & 8.0 & Tourism & 9 & 1.3 \\
\hline $\begin{array}{l}\text { Work situation post-UOC } \\
\text { other }\end{array}$ & 712 & 2.5 & & & \\
\hline
\end{tabular}

Source: UOC follow-up surveys, 2009 and 2012

to 38,671 euros in 2012, and the corresponding increase for women students was from 19,373 euros to 27,895 euros. For the pre-UOC earnings, we use the data these same respondents gave us when we first surveyed them in 2009, simply because it is likely their memory of these earlier earnings was more accurate in 2009 than in 2012.

Table 2 also reports average earnings by gender and for six types of study programs in which students enrolled. Programs are grouped into these types because the UOC administers their academic programs in these groupings and because of their categoryfirst or second cycle (second cycle degree programs require a first cycle degree to enroll) and a group of programs that require 4 years of study (licenciatura). We also report the average age of the students in each program at the time they enrolled and when they were surveyed in 2012. The oldest students were in the licenciatura programs-many of them 


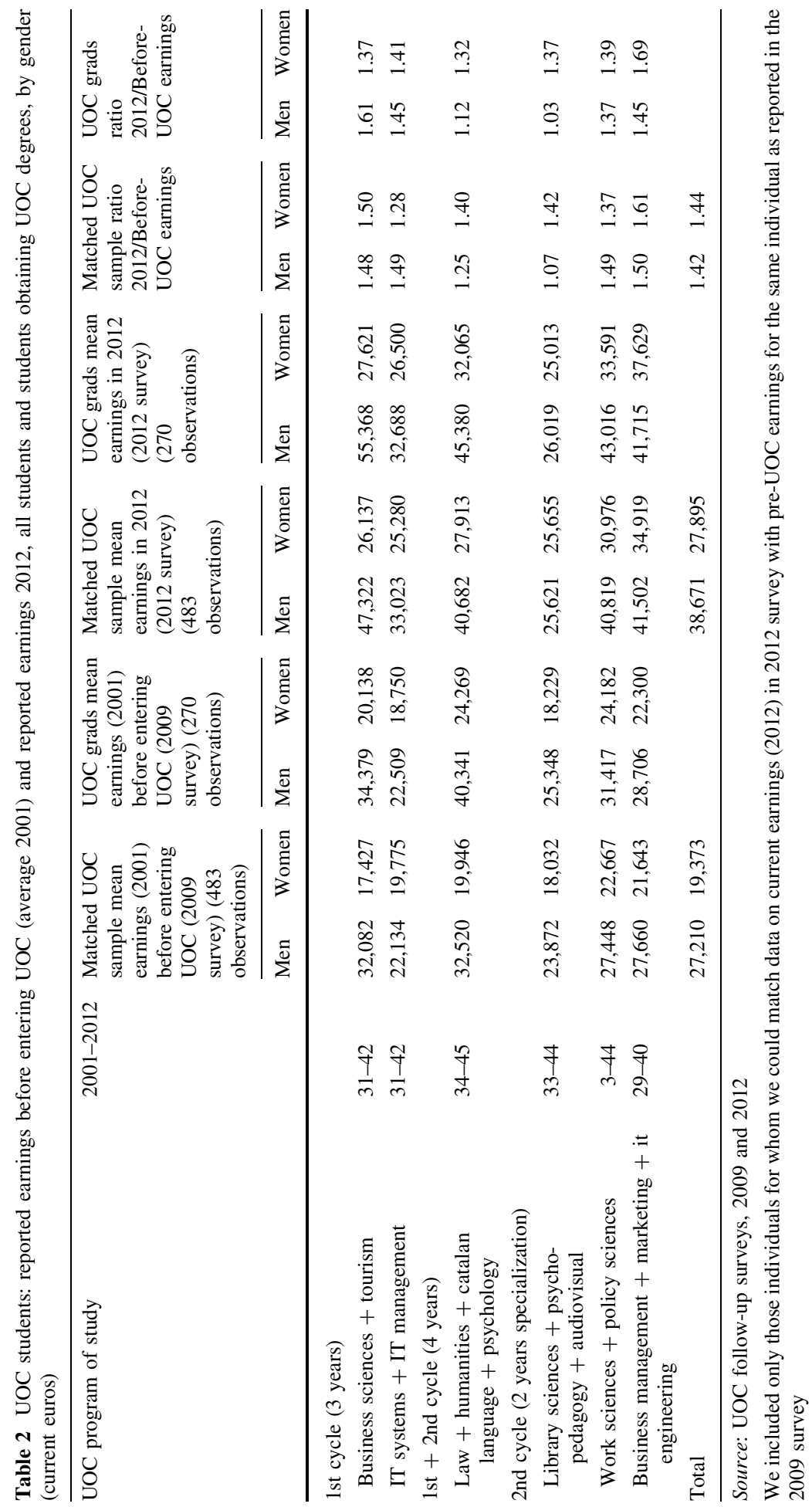




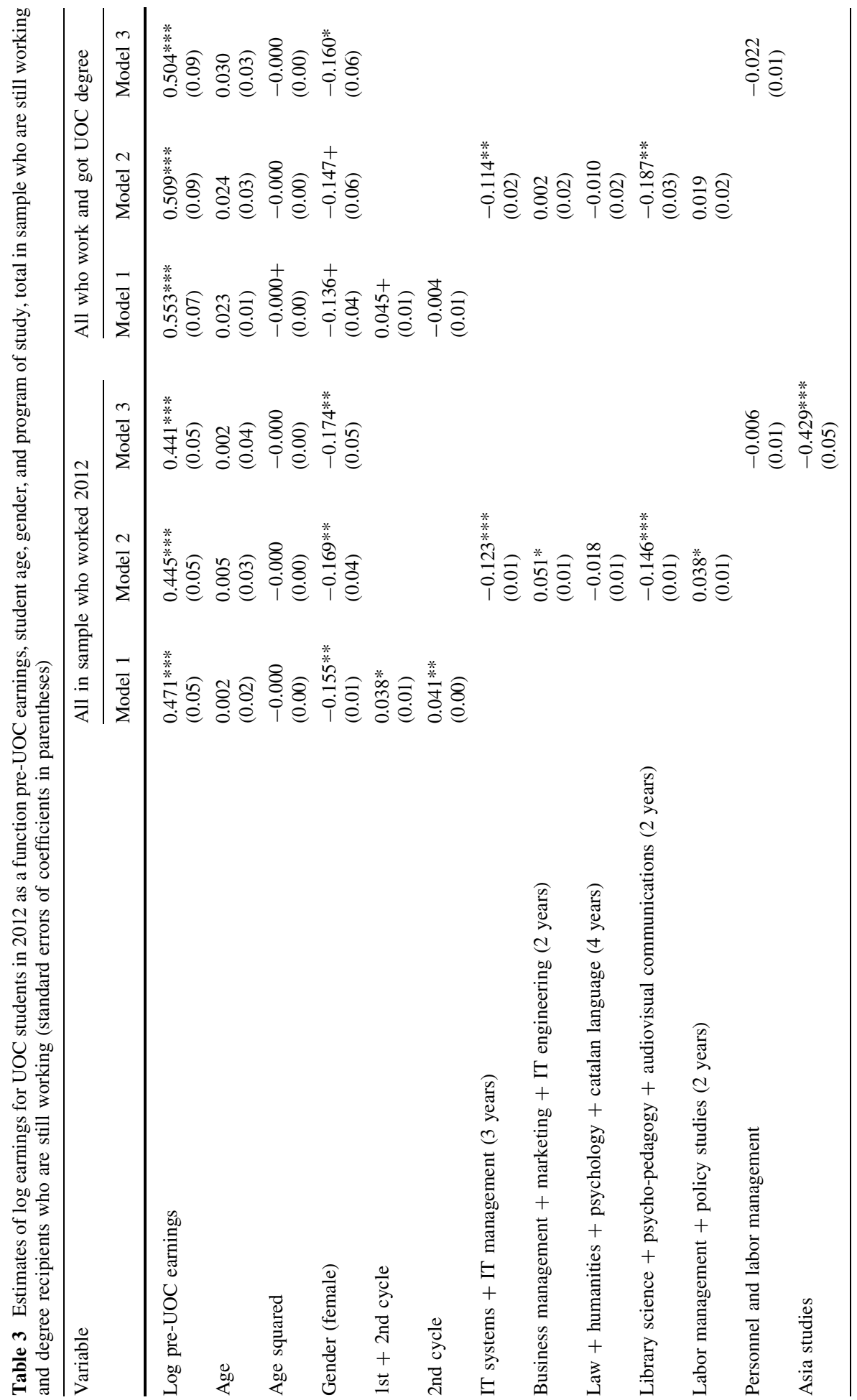




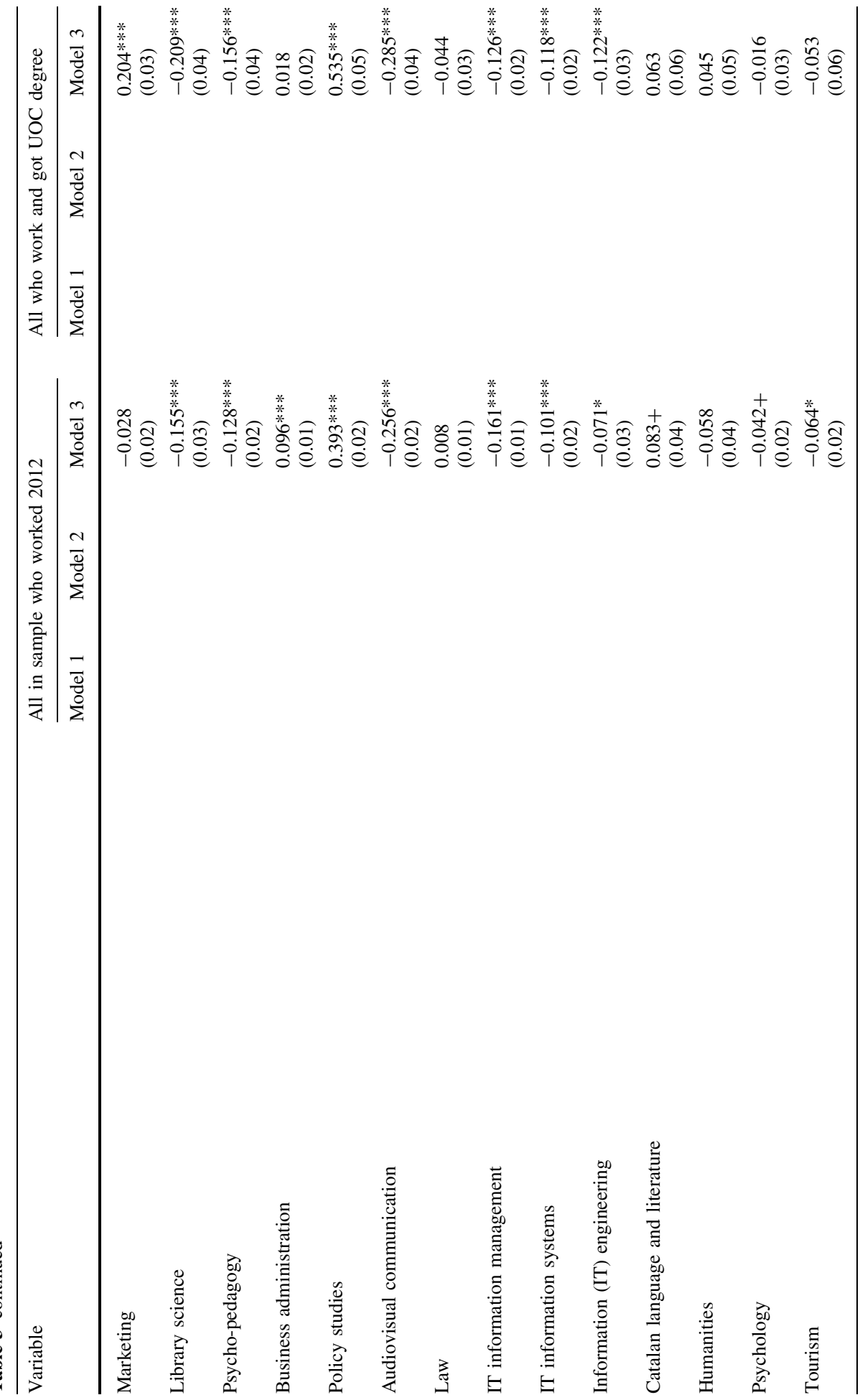




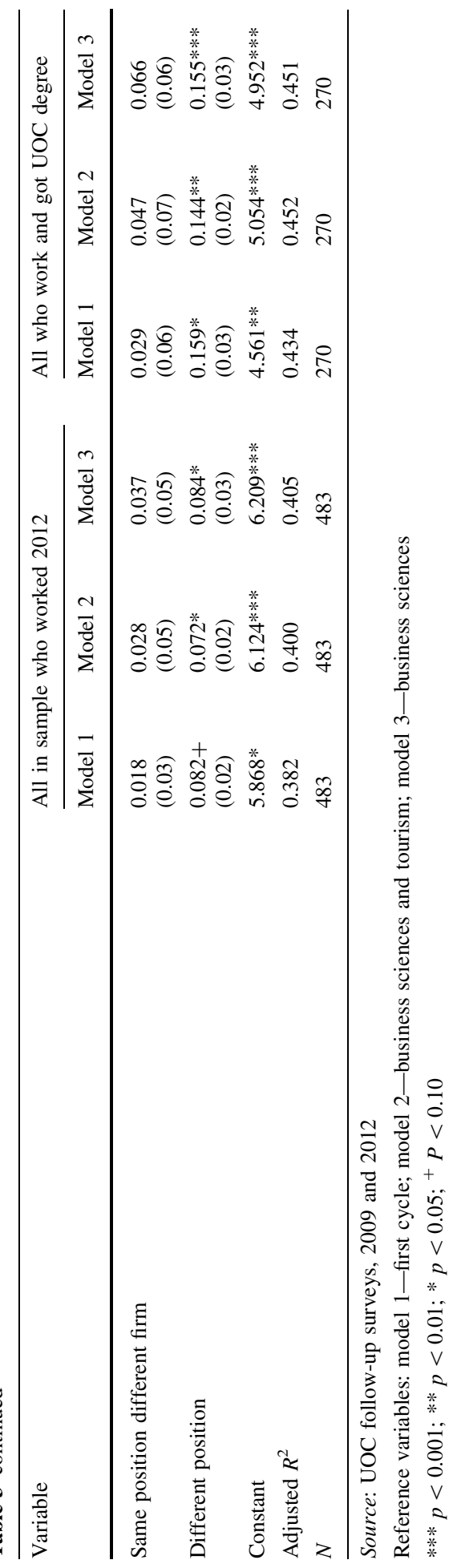


with previous university degrees or at least having spent time in traditional universities without completion.

The earnings gain ratios given in Table 2 for men and women are about the same overall, at over $40 \%$ (uncorrected for inflation), but the gains vary greatly among courses of study, for both men and women, but more for men, especially because the men who study in the education-related programs hardly increased their income. Males who graduated made somewhat smaller earning gains, and women grads, somewhat larger gains, than the overall group who studied at UOC.

\section{Estimating the effect of study program on earnings using regression analysis}

We can test whether these differences in earnings gains for those who are in different programs are statistically significant (after controlling for other covariates) by estimating the log of earnings for all those who responded in the 2012 survey, who are in the labor force (see Table 1), and for whom we have data both on their 2012 earnings and pre-UOC earnings. We also estimate earnings gains for those in the 2012 sample who obtained a degree from the UOC (Table 3). The dependent variable in these estimates is the log of 2012 annual earnings, and covariates of interest are the student's program of study and whether he or she switched firms or positions within firms in the period between enrolling in the UOC and when they were interviewed in 2012. We control for the worker's previous earnings (pre-UOC), following a standard method of estimating gains (in this case earnings gains). We also control for the worker's age, age squared, and gender.

Controlling for earnings "before UOC" should take care of most selection bias associated with ability, since earlier incomes reflect both earlier education (in part reflecting ability) and, in addition, ability effects over and above contributions to pre-UOC education. In our previous study of UOC earnings (Carnoy et al. 2012b), we also controlled for students' previous education and their parents' education in order to test whether these factors influenced the payoffs to different programs because of self-selection of students into those programs. The coefficients changed minimally when we added these variables, and this was also the case with this second follow-up sample.

The results in Table 3 suggest that controlling for pre-UOC earnings, gains for women are significantly lower (about 14 to $17 \%$ ) for both the total sample of matched UOC students and the sample of those who obtained a degree. Earnings gains appear to be somewhat higher for those who took shorter ( 2 year) programs and the longer 4-year programs than for the three-year diploma programs. This is the case for all employees but for the subset of UOC graduates, only those who took the longer 4-year programs appear have made marginally higher gains.

We find that those who studied in two groups of UOC programs - the IT Systems and IT Management diploma (3 years) programs and the Library Science, Psycho-pedagogy and Audiovisual Communications group of two-year programs (associated with employment in the educational system) - made significantly lower earnings gains than the reference group of programs (Business Sciences + Tourism). ${ }^{4}$ When we divide into specific individual programs, we find that, indeed, all the subprograms of study in each of the two groups are associated with significantly lower earnings gains than those who majored in Business Sciences associated with the period pre-UOC to 2012. Again, this is the case for both the

\footnotetext{
${ }^{4}$ We chose Business Sciences + Tourism as our reference program of study because earnings in this group are relatively high, and thus, the resulting negative coefficients of a number of other programs would likely be statistically significant.
} 
total sample of UOC students and those who obtained UOC degrees. We also find that UOC students who took the Policy Studies program made the largest earnings gains of any students in the sample, a full 39-54\% higher than UOC students who studied Business Sciences (the reference group) and all other programs of study.

Finally, we found that those in the sample who changed their position either in the same firm or by moving to another firm earned an additional 7-8 \% more, or, if they earned a degree, 14-16\% more than those who did not change position or the firm where they worked when they entered the UOC (the reference variable).

This could reflect student ability or motivation (lower ability or less motivated students did not change positions) - in which case, it is not the change that is responsible for higher earnings gains, but rather the unobserved characteristics of students who were able to make the change. Seen another way, controlling for this possible proxy for motivation/ability provides another correction for possible selection bias in the course of study selected by students. If more motivated individuals in our sample picked higher payoff programs, we would be overestimating the higher return to such programs. Controlling for changed position and changed firm should reduce the bias in the estimated coefficients for program of study.

As noted, estimates of the effects on earnings of studying in particular programs may also be biased because we did not include those who did not report earnings or were unemployed in 2012. When we imputed earnings for those who reported being employed, we increased the sample size to 543, and the coefficients for program of study for all workers and for graduates were unchanged from those estimated in Table 3 . When we examined the distribution of those 50 individuals in our 2012 sample who reported earnings in 2001, but reported being unemployed in 2012, we found that 19 of the 50 (38\%) had listed their program of study as business sciences (largely males). When we assign zero income to all those who were unemployed in 2012, the coefficients of some programs (personnel and labor management, marketing, psycho-pedagogy, business administration, and policy studies) relative to the reference variable, business sciences, rise considerably. But in others where unemployment is also significant (law, IT information management, IT information systems, information engineering, humanities, and psychology), the coefficients fall and remain negative. In general, with three exceptions-marketing, audiovisual communications, and tourism-even with the extreme zero income assigned to the unemployed, the programs of study associated with lower incomes remained lower, and those associated with higher incomes remained higher. ${ }^{5}$

\section{Does taking UOC courses pay off for UOC students?}

Do those who enroll in UOC do any better in their jobs than similar employees who did not? There may be various payoffs to taking a UOC education. Students may be promoted in their job, they may be able to change firms to take a job that they like better, they may earn a higher salary because they took classes or completed a course of study at the UOC (thus having learned something that helped them do their job better), or they may derive pleasure from learning new things (learning as consumption value).

As we showed in our earlier study (Carnoy et al. 2012b) and confirm with more detailed earnings data here, the earnings effect of a UOC degree or having completed coursework at UOC may be relative small but may bring less educated (especially older) employees' credentials into line with an already high salary. Former and current students in our survey

\footnotetext{
5 These regression results are available on request from the authors.
} 
were asked what they expected from their UOC education. Their answers, although probably influenced by what actually occurred in their lives once they left or completed their UOC studies, are interesting in terms of how we should weight the "payoffs" we measure. Individuals surveyed valued educational goals considerably more than economic or job goals. The most "relevant" goal was improving personal education-a consumption benefit. Among job (investment) goals, changing companies was least relevant to taking a UOC education, and getting a better job was most relevant. Yet, more than $50 \%$ of those surveyed considered obtaining a higher salary as very relevant or relevant. In terms of getting a better job, two-thirds said that this was very relevant or relevant.

To estimate job mobility, we were able to trace a more limited group of 467 individuals in the sample who answered the questions concerning pre-UOC and current occupations through the moves they made from their pre-UOC situation to what they did during UOC, and finally to 2012 when we surveyed them. These data are limited to whether an individual changed from being salaried employee to an administrator or self-employed entrepreneur (either with or without employees). Pre-UOC, $77 \%$ of this limited group reported that they were employees, $18 \%$ administrators, and $5 \%$ entrepreneurs. During the time they were enrolled in UOC, 84 of the 360 employees became administrators or entrepreneurs, 17 of the 83 administrators became employees or entrepreneurs, and seven of the 24 entrepreneurs became employees and administrators. By 2012, there was a clear net upward movement for the 467 individuals in this group-only $63 \%$ were employees, $28 \%$ administrators, and $9 \%$ entrepreneurs.

We have shown that the earnings gains of attending and completing the UOC are positive and vary across programs of study. Ideally, however, we would like to compare the earnings gains of those in our UOC sample with the gains in earnings of those in the labor force of similar age and the same starting educational level who did not take additional training. The best studies of adult learners—some of those cited earlier-make such comparisons. In our study, however, we have to make much more approximate estimates of UOC students' comparative earnings gains.

Our empirical strategy is to match-as closely as possible-the before and after reported earnings gains for workers in our UOC sample with the "baseline" gains for workers in the broader Spanish labor market in the same historical period. The advantage of the 2012 sample is that it allowed us to measure earnings for UOC students an average of 11 years after they entered, a period long enough for them to have realized whatever gains would accrue to their investment in courses or a degree from UOC.

To achieve the "match," we focused on the same individual UOC students who reported before- and after-UOC earnings by gender and their course of study (Table 2). This allows us to identify the level of university education in which each group studied (first cycle, second cycle, first plus second cycle), and the earnings gains associated with each level of education and gender, as reported in Table 2. We assume that those who studied in first cycle courses only held an upper secondary degree, or bachillerato, when they began their UOC studies and that those who studied in a second cycle course only held a first cycle university degree. These assumptions are, in fact, mainly correct, according to our survey data. We found that those in the first plus second cycle courses were mixed in their previous degree, and we weight the outcomes by the percent in each category.

Second, to compare the gains shown in Table 2 with the Spanish labor force's experience-related gains, we estimated the average length of time that passed between pre-UOC earnings (entry to UOC) and 2012 (this was 11 years for all groups), and the average age at entry and 11 years later. This age range made it possible to fix the comparable ages on Spanish labor market age-earnings curves for those with the bachillerato degree and the 


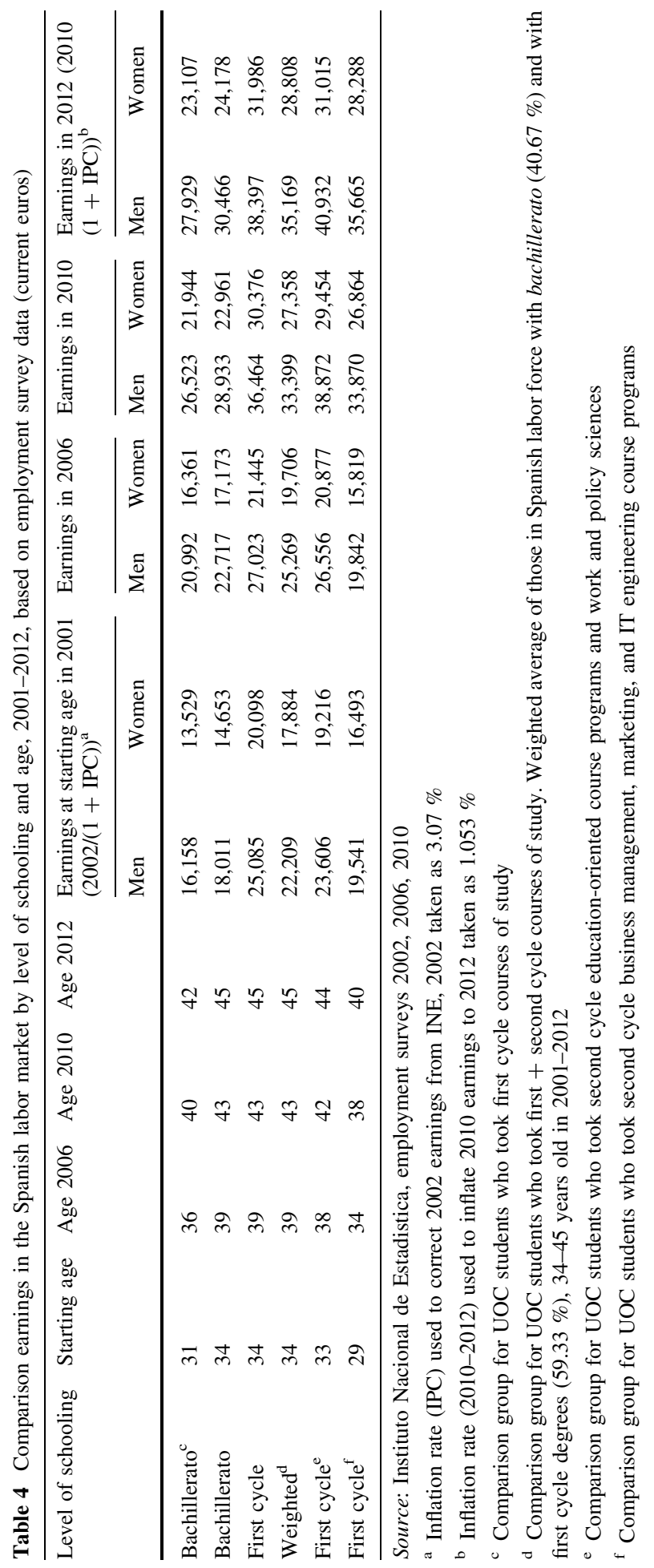


first cycle degree. Thus, if we use the average age at enrollment of students in each program as the starting point, we can estimate the age range over which, on average, students began and ended their studies in each program. Although men and women's mean age varied somewhat in these various fields of study, they were close enough to use the same age range for both.

In addition, Table 2 shows the earnings gains by program of study for a second, smaller subgroup - those in our survey who reported before-UOC and 2102 earnings and "graduated" (completed a course of study for a degree) from UOC. These individuals tended to have higher earnings both "pre-UOC" and in 2012, but not necessarily a higher "gain" in earnings (as measured by the ratio of 2012/pre-UOC earnings).

Turning to the Spanish 2002 and 2010 age-earnings profiles (for the relevant education levels) estimated from the Spanish employment surveys (Table 4), we can calculate the earnings increases for men and women with a bachillerato (end of secondary school degree required for those entering UOC first cycle and first plus second cycle programs) between the ages corresponding to the UOC starting and ending ages for the two groups of first cycle programs and the first plus second cycle programs (law, psychology, humanities) shown in Table 2. We can also estimate similar earnings increases for those with first cycle degrees (required for UOC second cycle programs) between the beginning and ending ages of UOC students who studied in the three second cycle programs in Table 2. These estimated gains represent what UOC students would have earned hypothetically if they had not studied at UOC - essentially, the earnings gains from more years in the labor force, which captures productivity increases from on-the-job learning and customary seniority pay increases.

We make these estimates in four steps: a) We estimate the earnings at the appropriate level of education and gender at the "starting age" from the Instituto Nacional de Estadística (INE) database-estimated 2002 age-earnings profiles; (b) we adjust the 2002 earnings for the inflation rate in 2001-2002 (3.1\%) to estimate 2001 earnings (the average starting year for UOC students in our survey); (c) we estimate the earnings in 2010 for the same education and gender at the 2012 age in our sample minus 2 years; and (d) we adjust the 2010 earnings for the appropriate education and gender up to an approximated 2012 earnings level using the increase in the consumer price index in 2010-2012 (4.3\%). ${ }^{6}$

Thus, a male with a bachillerato degree 31 years old in 2002 earned an average 16,654 euros. In 2001, he would have earned 16,158 euros. In 2010, according to the INE ageearnings profiles for that year, a 40-year-old male with a bachillerato degree would have earned an average 26,523 euros. To estimate what he would have earned 2 years later, at 42 years old, we estimated the growth rate of earnings in 2006-2010 of male bachillerato holders 35-44 years old at the inflation rate, or $4.3 \%$ total for the 2 years. Adjusting the 26,523 euros by that $4.3 \%$, we estimated the 2012 earnings for a male 42 years old with a bachillerato degree at 27,929 euros. We made similar estimates for the other categories. These estimates represent the earnings gains in the Spanish labor force for workers as they gained experience but did not change their education levels.

When we compare the Spain-wide absolute earnings estimates by level of education at the starting and ending ages given in Table 4 with the earnings of those in the UOC sample

\footnotetext{
${ }^{6}$ We lack the data to estimate how much the average employee in the Spanish labor market with a upper secondary (bachillerato) degree or first cycle university degree invests in additional education in his or her thirties (the age group most represented at UOC). We assume that that investment is small. This would make any earnings increases in the labor market associated with higher age the result of on-the-job learning or "customary" pay increases that occur with seniority.
} 
reported "before UOC" and in 2012 given in Table 2, the earnings are lower for Spanish workers as a whole except for Library Sciences + Psycho-pedagogy + Audiovisual group (Table 2 compared with Table 4, first cycle, 33 years old in 2001). These lower earnings in the overall Spanish labor market obtain for both men and women, and especially for the bachillerato level.

This suggests that our assumptions about the comparability of UOC students in first and first plus second cycle programs with those in the Spanish labor force as a whole holding bachillerato degrees may not be valid, on three levels: (a) UOC students studying in first cycle programs may, on average, be likely to have more years of schooling than a just completed secondary school (the bachillerato); (b) even those UOC students with only secondary school completed may be very untypical of secondary school completers in the Spanish labor force as a whole, namely that they are in jobs that pay much higher salaries than the average for their level of education and age; and (c) UOC students in 2001 may have varied greatly in age and therefore may have a larger variance of starting incomes than workers with a particular year of age we used as a reference group. Although the differences in the pre-UOC earnings of UOC students and those in the Spanish labor force with first cycle degrees are not as extreme, two groups of the UOC students in second cycle degree programs also have much higher pre-UOC earnings than their counterparts in the Spanish labor force.

Keeping this in mind, the earnings gain "ratios" first reported in Table 2 and again, for UOC students compared with their counterparts from the Spanish labor market, in Table 5, are considerably lower for most UOC students than for their average counterpart in the Spanish labor market (Table 5). The results suggest that both those in our UOC sample who entered with bachillerato degrees and pursued first cycle courses of study and those

Table 5 Ratios of earnings 2012/2001 of UOC students and Spanish labor market comparison groups

\begin{tabular}{|c|c|c|c|c|c|c|c|}
\hline \multirow[t]{2}{*}{ UOC program of study } & \multirow[t]{2}{*}{$\begin{array}{l}\text { Age } \\
2001-2012\end{array}$} & \multicolumn{2}{|c|}{$\begin{array}{l}\text { Matched UOC } \\
\text { sample ratio } \\
\text { 2012/before- } \\
\text { UOC earnings } \\
\text { (2001) }\end{array}$} & \multicolumn{2}{|c|}{$\begin{array}{l}\text { UOC } \\
\text { graduates ratio } \\
\text { 2012/before- } \\
\text { UOC earnings } \\
\text { (2001) }\end{array}$} & \multicolumn{2}{|c|}{$\begin{array}{l}\text { Spanish labor } \\
\text { market ratio } \\
2012 / 2001 \text { of } \\
\text { comparison } \\
\text { group earnings }\end{array}$} \\
\hline & & Men & Women & Men & Women & Men & Women \\
\hline \multicolumn{8}{|l|}{ First cycle (3 years) } \\
\hline Business sciences + tourism & $31-42$ & 1.48 & 1.50 & 1.61 & 1.37 & 1.73 & 1.71 \\
\hline IT systems + IT management & $31-42$ & 1.49 & 1.28 & 1.45 & 1.41 & 1.73 & 1.71 \\
\hline \multicolumn{8}{|l|}{ First + second cycle (4 years) } \\
\hline $\begin{array}{l}\text { Law }+ \text { humanities }+ \text { catalan } \\
\text { language }+ \text { psychology }\end{array}$ & $34-45$ & 1.25 & 1.40 & 1.12 & 1.32 & 1.58 & 1.61 \\
\hline \multicolumn{8}{|l|}{ Second cycle (2-year specialization) } \\
\hline $\begin{array}{c}\text { Library sciences }+ \text { psycho- } \\
\text { pedagogy }+ \text { audiovisual }\end{array}$ & $33-44$ & 1.07 & 1.42 & 1.03 & 1.37 & 1.73 & 1.61 \\
\hline Work sciences + policy sciences & $33-44$ & 1.49 & 1.37 & 1.37 & 1.39 & 1.73 & 1.61 \\
\hline $\begin{array}{l}\text { Business management } \\
\quad+\text { marketing }+ \text { IT engineering }\end{array}$ & $29-40$ & 1.50 & 1.61 & 1.45 & 1.69 & 1.83 & 1.72 \\
\hline
\end{tabular}

Source: Surveys of UOC student cohort 2000-2002/2003, 2009, and 2012 estimated from earnings in Tables 2 and 4 
who entered second cycle or first plus second cycle courses had smaller relative increases in earnings than those in the Spanish labor market simply from experience and seniority gained over 11 years of working.

For example, men in UOC's first cycle business sciences and tourism programs gained $48 \%$ in earnings (a ratio of 1.48 in Table 5), whereas a comparable male age group of similar initial education in the Spanish labor force gained $73 \%$ in the same period (a ratio of 1.73 in Table 5). The gains were similarly lower for students who took second cycle courses. For example, women who took UOC's second cycle business management program made a large $61 \%$ nominal earnings gain (Table 5), whereas the comparable group in the Spanish labor force made an even larger $72 \%$ gain in this same period. These estimates suggest that in terms of percentage earnings gains compared to Spanish workers with baseline bachillerato or first cycle degrees, it is unlikely that UOC students realized a positive return to investing in courses toward either first cycle, second cycle, or licenciatura degrees in law, humanities, psychology, and Catalan language and literature programs.

Part of the explanation for the lower ratios may lie in the fact that all the earnings shown in Table 2 are self-reported. They may not reflect the true gain that UOC students realize from taking UOC programs. It is likely that there is greater error in the reporting of preUOC earnings than more recent earnings. Although we used the earnings reported in the first follow-up survey in 2009, this was still, on average, 8 years after the actual time they were being asked to report on. It could well be that these earnings from 8 years in the past were reported as higher than they actually were, biasing downward all our estimated returns for UOC students. A second reason for lower gains in earnings for UOC students may be that the UOC degree or attending UOC has lower value as a labor market "signal" (Spence 1973; Deming et al. 2014) than the average Spanish university. Online universities such as UOC do very poorly in "traditional" university ranking systems. U-Multirank is one of the few rating systems that directly ranks the UOC, and they rate UOC quite low compared to other Spanish and European universities. ${ }^{7}$ Yet, as we show below, this reason is much less persuasive when we divide the sample into initially high and low earners.

A third reason may be that about three-quarters of our UOC follow-up sample is from Catalonia, and salaries in Catalonia are higher than average Spanish salaries. We estimated earnings by age and level of education for Catalonian and the total of Spanish full-time employed workers from the Spanish (INE) employment surveys in 2002 and 2010. We focused on workers with post-secondary professional education and with university education. In both years, earnings in Catalonia were about $2 \%$ lower to $10 \%$ higher for females, and 5-10\% higher for males. Younger female workers in Catalonia with university education made the largest gains in the 8 years, about $12 \%$, and female workers with post-secondary education in Catalonia made larger gains generally than female Spanish workers with similar education, from 0 to $12 \%$ higher gains. However, male workers in Catalonia made essentially the same gains as their counterparts with postsecondary education in Spain as a whole. If the premium were smaller in 2010 than in 2002, it would help explain why the earnings gains for our UOC sample are smaller than for gains in the overall Spanish labor market; however, that is not the case. Indeed, if anything, the female earnings gains for the UOC sample were helped by the general trend that favored Catalonian female earnings gains in this period. Yet, the results in Table 5

\footnotetext{
7 See http://www.umultirank.org/\#!/explore?trackType=explore\&sightMode=undefined\&detailUniversity= 1731\&section=exploreUniversityDetail. Accessed April 30, 2015.
} 


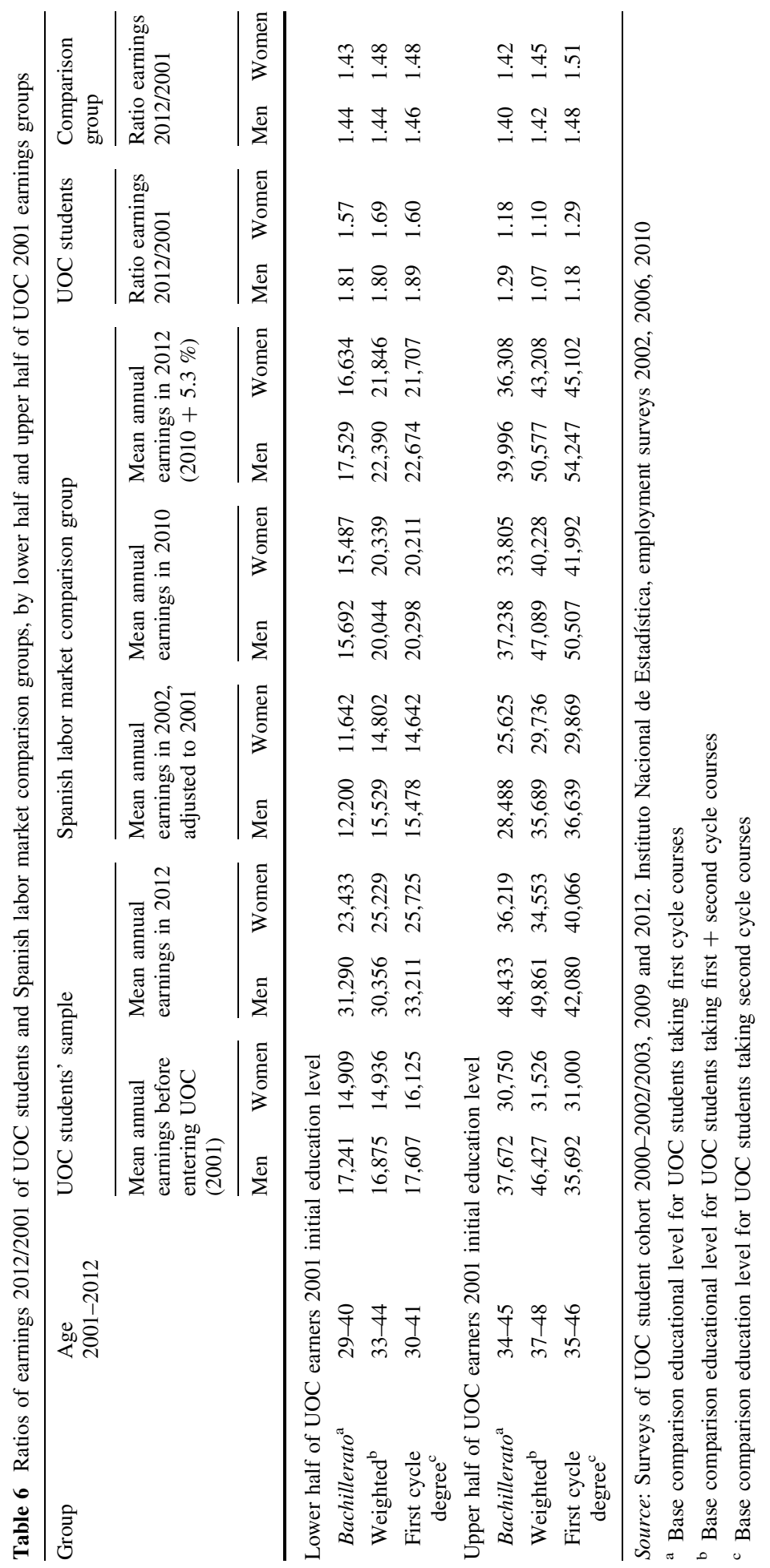


suggest that our UOC sample women did not make as large gains as Spanish women as a whole during this period.

A fourth reason, and most persuasive reason for the smaller gains by UOC students, is that, except for the special case of those taking the Library Sciences, Psycho-pedagogy, and Audiovisual programs (associated with relatively low-paying education jobs), UOC students appear to have been earning considerably more than average Spanish labor market earnings when they first enrolled in the UOC. There may have been less "room" for further gains. Thus, as discussed above, their motivation to get a degree may have been as much about maintaining their absolute earnings advantage rather than making relative gains. If our sampled students tend to represent employees who are under-degreed relative to their job position and earnings, they could be highly motivated to seek a degree that would legitimate their absolute advantage. We also observe from the estimates in Table 2 that for those who began their UOC studies with a bachillerato degree, UOC students stayed well above the earnings of their bachillerato counterparts in the Spanish labor market. They effectively maintained their higher absolute earnings, even though their relative gains were lower. UOC students who graduated with second cycle degrees also maintained higher salaries than average workers with similar degrees in the Spanish labor market.

To explore this issue further, we divide our UOC sample into those students in the lower half of initial earnings in 2001 and those in the upper half. We determined that those in the lower half of earnings were 4-5 years younger on average when entering UOC than those in the upper half of the earnings distribution. We use this differential age range to estimate comparison salaries from the INE data for 2002 and 2010 and bring these down to 2001 and up to 2012 as given in Table 4. The results are given in Table 6.

These results suggest that the 2001 and 2012 earnings of UOC students remained higher than average Spanish labor market earnings for the lower half of earnings group; this was not generally true for the upper half of UOC earning group. The top half of earnings in the Spanish labor market were higher in 2012 for those with first cycle degrees in 2012 than the earnings of the top half of UOC students who had studied in licenciatura second cycle programs. At the same time, the gains of UOC students who initially were in the lower half of UOC students' earnings ended up with much higher gains than their comparison group in the Spanish labor market. The opposite was true for the (older) UOC students who had initial earnings in the top half of UOC earners.

In our sample, we know that about one-third of UOC business sciences first cycle students, one-fourth of IT first cycle students, and more than one-half of law, psychology, and humanities (first and second cycle students) had at least some university education before entering UOC. This, in addition to their higher age, could explain part of the higher earnings before UOC, particularly for those in the top half of initial earners. Catalan salaries also tend to be higher than the Spanish average. Yet, beyond these explanations, particularly for the lower half, younger first cycle and second cycle UOC students, their higher "before-UOC" earnings suggest that they may have been more motivated and more productive than the average Spaniard or Catalan employee before entering UOC, and the fact that they chose to take UOC courses is probably in keeping with this greater motivation.

We suggest as well that one important reason that older employees who are "underdegreed" relative to their jobs and salaries (or "overpaid" relative to their degree), such as the upper half earners in our sample, enroll in UOC may be to "legitimize" their earnings by obtaining degrees consistent with their jobs or job track. In that case, they may not have made significant earnings gains as a result of their higher degree, but they may have protected their position in the job market or in the firm. This is consistent with Spain's 
generally low-mobile labor market, where employees may be very concerned about legitimizing their position in a job as they age, particularly if they are "undereducated" relative to the average for their job.

We also should not underestimate the "lifelong learning" consumption aspects of some of the programs. For example, given that many (about $60 \%$ ) of those who enrolled in the law, psychology, humanities, and Catalan language and culture courses of study already have first cycle and first plus second cycle degrees, it is entirely possible that they enrolled for learning's sake, without seeking job-related gains from their UOC experience. This would be consistent with our findings that these generally much higher than average earning older individuals made much less than average gains compared to their counterparts in the Spanish labor force, yet maintained their generally high earnings position in absolute terms. It is also consistent with our findings shown elsewhere (Carnoy et al. 2012a) that less than one-fourth of these students complete their degree.

\section{Discussion and conclusions}

Our estimates of the economic benefits to working adults investing their time in online higher education in Catalonia and Spain suggest that students studying in some programs do make larger earnings gains as a result of having studied in the UOC than students in other programs. Overall, these gains were not nearly as large as the earnings increases made by average workers in the Spanish labor market as a whole as they moved up the ageearnings profile over the same eleven-year period (2001-2012).

Why would UOC students make such lower percentage earnings gains than their counterparts in the overall Spanish labor market? One reason may be simply that the reported earnings in our sample are inaccurate, especially for the "before-UOC" period. Another may be that the "signal" value of a UOC education is much lower than attending traditional Spanish universities. Yet another reason may be that in estimating such earnings gains for UOC students, we face selection bias issues in terms of the much higher salaries of the sampled individuals who enter distance education studies than the salaries of the comparison groups-average workers and employees in the labor market with similar education levels and of the same age.

We analyzed this possible bias by dividing the sample into those UOC students who reported salaries in the upper half of the distribution when they began their studies in 2001, and those in the lower half of reported "before-UOC" earnings. We found that those UOC students with higher initial earnings were about 5 years older than those with lower initial earnings. We compared them with their "age-education counterparts" in the Spanish labor market and found that they began with much higher salaries but made much lower gains. The (younger) UOC students in the lower half of the initial earnings distribution also had somewhat higher beginning earnings than their Spanish labor market counterparts, but the UOC students had generally higher earnings gains than those with corresponding education and age in the labor market as a whole.

This suggests that there may be a high earnings payoff to studying at UOC for higher degrees, but it is limited to students who begin at somewhat younger than average age. They end up (11 years later) with considerably higher earnings than their counterparts in the Spanish labor market. Those who start UOC at higher ages already were earning much higher salaries than their counterparts in the Spanish labor market if they only had a bachillerato degree (studying for a 1st cycle degree or for a licenciatura (first plus second 
cycle degree). Men studying for a second cycle degree had lower initial salaries, but women had somewhat higher salaries than their Spanish labor market counterparts. However, in all but one case-men with bachillerato degrees when they began studying at the UOC in 2001 - the people who studied at UOC ended up in 2012 with the same of lower salaries than their counterparts in the Spanish labor market who, we assume, did not take further studies. Thus, these older UOC students generally had higher initial salaries but in every category made smaller gains than their education-age counterparts who did not take further studies.

The result is logical from several perspectives. Human capital theory would predict that older investors in education are less likely to realize as large a gain as younger investors. However, the generally higher initial salaries for the older UOC investors could mean that they were very "unusual": compared to other workers with similar levels of education, and that they used UOC studies just to maintain (to legitimate) their already high salaries. It is also likely that if the pre-UOC earnings they report are accurate, that they were unusually productive compared to other workers of similar age with bachillerato degrees. This was also true of the younger UOC students with bachillerato degrees, but they also ended up making much larger earnings gains than their counterparts in the labor market, so "studying to legitimate" salary or "acquiring the appropriate education signal" for their job position is a less compelling argument for these younger adult workers.

Thus, although we have been able to cut through one possible explanation of why average earnings gains are higher in the Spanish labor market than the average earnings gains for those who studied in UOC, it still seems to hold that those adult workers who chose to study in UOC are not particularly representative of those in the Spanish labor market. Our sample of UOC students from the 2000-2002/2003 cohorts reported higher initial salaries, and in many categories, much higher salaries, than the average for their age and education group in 2001.

There are other issues with our ability to compare earnings of our UOC students with the appropriate counterparts in the Spanish labor market. Our UOC earnings comparisons with Spanish age income profiles over time-useful as they are-compare students in specific programs of study in UOC that to some extent reflect their occupations with average earnings in the Spanish labor market not identified by occupation. The most obvious problem with such comparisons emerges when we compare the earnings gains of those students who took courses and degrees in Library Science, Psycho-pedagogy, and Audiovisual studies, programs that appeal particularly to those with careers in the relatively low-paying education sector. Our estimates suggest that earnings gains are small for UOC students when compared to overall earnings gains in 2001-2012 for average Spanish workers with first cycle degrees. Yet, psycho-pedagogy is a highly popular course of study at UOC. Why? First, we observe that for UOC women students, the gains are much higher in this course of study than for men, and indeed, it is women who are the main clients for this program. In addition, if we had the data, it would be far more relevant to compare UOC student earnings gains with the earnings gains in education occupations in this same period of 2001-2011. We may find that UOC women students of these three courses had done far better earnings-wise than the "right" comparison group.

With so many employed adults enrolling in distance education, it is important to get an accurate picture of the benefits that they realize from doing so. Our study suggests that there are many reasons that adults enroll in such programs. It also suggests that for younger adult learners investing in a UOC education does produce quite large relative earnings gains. For older UOC adult learners, this is not the case. Yet, it could well be that the higher earnings objective may be less of a main reason to be studying at UOC than 
legitimizing the earnings and work position they already have, allowing them to acquire skills that maintain or somewhat enhance their jobs, or simply to consume knowledge for its own sake. Any of these bring new students into virtual universities and other forms of distance education as long as it is low cost. And, indeed, UOC is low-cost higher education, because although students may have to pay a relatively high price in terms of leisure, their income foregone while studying is close to zero. In terms of fees, it is also quite low cost, particularly for Catalans, because the Catalan government subsidizes it. Spanish students have to pay more and, interestingly, are more likely to complete their studies with a degree (Carnoy et al. 2012a), but at the monthly fees charged, our study suggests that, at least for certain programs of study and for younger investors, the rate of return could be rather high.

Acknowledgments We want to thank the Open University of Catalonia for funding and carrying out the basic data collection on which this article is based. The article was also prepared within the framework of the Basic Research Program at the National Research University Higher School of Economics (HSE) in Moscow. The views expressed in this article are purely those of the authors and may not in any circumstances be regarded as stating an official position of the European Commission, the Open University of Catalonia, or the National Research University Higher School of Economics.

Open Access This article is distributed under the terms of the Creative Commons Attribution 4.0 International License (http://creativecommons.org/licenses/by/4.0/), which permits unrestricted use, distribution, and reproduction in any medium, provided you give appropriate credit to the original author(s) and the source, provide a link to the Creative Commons license, and indicate if changes were made.

\section{References}

Ben Youssef, A., Ben Youssef, H., \& Dahmani, M. (2013). Higher education teachers' e-skills and the innovation process. International Journal of Computer and Information Technology, 2(2), 185-195.

Bennion, A., Scesa, A., \& Willams, R. (2011). The benefits of part-time undergraduate study and UK higher education policy: A literature review. Higher Education Quarterly, 65, 145-163.

Blanden, J., Buscha, F., Sturgis, P., \& Urwin, P. (2012). Measuring the earnings returns to lifelong learning in the UK. Economics of Education Review, 31, 501-514.

Blundell, R., Dearden, L., Goodman, A., \& Reed, H. (1997). Higher education, employment and earnings in Britain. London: Institute for Fiscal Studies.

Carnoy, M., Jarillo, B., Castaño-Muñoz, J., Duart-Montoliu, J. M., \& Sancho-Vinuesa, T. (2012a). Who attends and completes virtual universities: The case of the Open University of Catalonia (UOC). Higher Education, 63(1), 53-82.

Carnoy, M., Jarillo, B., Castaño-Muñoz, J., Duart-Montoliu, J. M., \& Sancho-Vinuesa, T. (2012b). Does online distance higher education pay off for adult learners? The case of the Open University of Catalonia (UOC). Higher Education Quarterly, 63(3), 248-271.

Castaño-Muñoz, J., \& Senges, M. (2011). Youth-culture or student-culture? The internet use intensity divide among students and the consequences for academic performance. Estudios sobre Educación, 20, 203-231.

Castaño-Muñoz, J., Duart-Montoliu, J. M., \& Sancho-Vinuesa, T. (2014). The internet in face-to-face higher education: Can interactive learning improve academic achievement? British Journal of Educational Technology, 45(1), 149-159.

De-Coulon, A., \& Vignoles, A. (2008). An analysis of the benefit of NVQ2 qualifications acquired at age 26-34. Centre for the Economics of Education Discussion Paper 106.

Deming, D., Yuchtman, N., Abulafi, A., Goldin, C., \& Katz, L. (2014). The value of postsecondary credentials in the labor market: An experimental study. Cambridge, MA: National Bureau of Economic Research, NBER Working Paper No. 20528.

Dorset, R., Liu, S., \& Weale, M. (2010). Economic benefits of lifelong learning. London: Centre for Learning and Life Chances in Knowledge Economies and Societies (LLAKES), University of London, Research Paper 13. 
Egerton, M., \& Parry, G. (2001). Lifelong debt: Rates of return to mature study. Higher Education Quarterly, 55(1), 4-27.

Hällsten, M. (2012). Is it ever too late to study? The economic returns on late tertiary degrees in Sweden. Economics of Education Review, 31, 179-194.

Instituto Nacional de Estadística (INE). (2015). Wage structure survey 2002, 2006 and 2010. Data available at http://www.ine.es/en/prodyser/micro_salarial_en.htm. Accessed April 15, 2015.

Jenkins, A., Vignoles, A., Wolf, A., \& Galindo-Rueda, F. (2002). The determinants and effects of lifelong learning. London: Centre for the Economics of Education, London School of Economics and Political Science.

Ladd, H. (2008). Teacher effects: What do we know? In G. Duncan \& J. Spillane (Eds.), Teacher quality: Broadening the debate. Evanston, IL: Northwestern University.

Lanvin, B., \& Passman, P. (2008). Building e-skills for the Information Age. Global Information Technology Report. World Economic Forum/INSESD. http://www.ecdl.org/files/cepis/20091106035314_ BuildingE-skillsfortheInformat.pdf.

Lassibille, G., \& Navarro Gomez, M. L. (2009). Tracking students' progress through the Spanish university school sector. Higher Education, 58(6), 821-839.

Myers, K. L., \& Myles, J. F. (2005). Self-assessed returns to adult education: Life-long learning and the educationally disadvantaged. Paper presented at the annual meeting of the American Sociological Association, Marriott Hotel, Loews Philadelphia Hotel, Philadelphia, PA. http://www.allacademic. com//meta/p_mla_apa_research_citation/0/2/0/3/7/pages20373/p20373-7.php.

Organization for Economic Cooperation and Development. (2003). Education policy analysis. Paris: OECD.

Ozdemir, Z. D., Altinkemer, K., \& Barron, J. M. (2008). The adoption of technology-Mediated learning in the U.S. Decision Support Systems, 45, 324-337.

Spence, M. (1973). Job market signaling. Quarterly Journal of Economics, 87(3), 355-374.

Steel, J., \& Sausman, C. (1997). The contribution of graduates to the economy-Rates of return. London: National Committee of Inquiry into Higher Education (Dearing Committee), Report 7.

UNESCO. (2015). UNESCO statistics. Data Centre. http://www.uis.unesco.org/Datacentre/Pages/ instructions.aspx?SPSLanguage=EN. Accessed May 15, 2015.

Woodley, A., \& Simpson, C. (2001). Learning and earning: Measuring 'rates of return' among mature graduates from part-time distance courses. Higher Education Quarterly, 55(1), 28-41. 